\title{
Morphological, chemical and physiological characterization of Amaranthus spp. seeds ${ }^{1}$
}

\author{
João Barcellos Xavier² (iD, Dayliane Bernardes de Andrade ${ }^{2}$ (D), Douglas Correa \\ de Souza $^{2 *}$ (D), Gabriel Castanheira Guimarães ${ }^{2}$ (D), Luciane Vilela Resende² (D, \\ Renato Mendes Guimarães ${ }^{2}$
}

\begin{abstract}
Amaranthus species have great potential for human food due to their nutritional and functional properties, but there are few phytotechnical studies with this crop, making its cultivation unfeasible. Aiming to encourage the production of these species, this study aimed to evaluate and distinguish the morphological, chemical and physiological characteristics of seeds of Amaranthus sp. (commercial species), A. viridis and A. hybridus. The experiments were performed in a completely randomized design, evaluating seeds in size classes $(850,600$ and $425 \mu \mathrm{m})$ and characterizing them by image analysis using the GroundEye ${ }^{\mathbb{B}}$ system, near-infrared spectroscopy (NIR) and radiographic analysis. The first germination count, germination and germination speed index with and without $\mathrm{KNO}_{3}$ were performed to evaluate the physiological quality of seeds. The results were submitted to analysis of variance and the means compared by the Tukey test. Radiographic analysis showed that the seeds of the three studied species were filled in the size class of 600 and $850 \mu \mathrm{m}$, without dormancy, but the commercial species had higher germination speed. GroundEye ${ }^{\circledR}$ and NIR allowed distinguishing the three species according to their geometric characteristics, predominance of color and chemical components.
\end{abstract}

Index terms: unconventional vegetables, GroundEye ${ }^{\circledR}$, near-infrared spectroscopy, radiographic analysis.

\section{Caracterização morfológica, química e fisiológica de sementes de Amaranthus spp.}

RESUMO - As espécies do gênero Amaranthus possuem grande potencial para alimentação humana, devido às suas propriedades nutricionais e funcionais, entretanto existem poucos estudos fitotécnicos com a cultura inviabilizando o seu cultivo. Visando incentivar a produção dessas espécies objetivou-se com essa pesquisa avaliar e distinguir as características morfológicas, químicas e fisiológicas das sementes de Amaranthus sp. (espécie comercial), A. viridis e A. hybridus. Os ensaios foram realizados em delineamento inteiramente casualizados avaliando as sementes em classes de tamanho $(850 \mu \mathrm{m}, 600 \mu \mathrm{m}$ e 425 $\mu \mathrm{m})$ e caracterizando-as por análise de imagens utilizando o sistema GroundEye ${ }^{\circledR}$, espectroscopia de infravermelho próximo (NIR) e análise radiográfica. Para avaliação da qualidade fisiológica das sementes realizou-se o teste de primeira contagem de germinação, germinação e índice de velocidade de germinação com e sem uso de $\mathrm{KNO}_{3}$. Os resultados foram submetidos à análise de variância e as médias comparadas pelo teste de Tukey. Pela análise radiográfica foi possível observar que as sementes das três espécies estudadas se apresentam cheias na classe de tamanho de 600 e $850 \mu \mathrm{m}$, e não possuem dormência, no entanto a espécie comercial possui maior velocidade de germinação. Por meio do GroundEye ${ }^{\mathbb{R}}$ e do NIR foi possível distinguir as três espécies, de acordo com as características geométricas, e predominância de coloração e componentes químicos.

Termos para indexação: hortaliças não convencionais, GroundEye ${ }^{\circledR}$, espectroscopia de infravermelho próximo, análise radiográfica.

\section{Introduction}

Plants of the genus Amaranthus have been considered as foods of the future due to their nutritional and functional properties, such as high content of antioxidants and dietary fibers, and may be an alternative for the diversification of human nutrition (Amaya-Farfan et al., 2005; Silva et al., 2018; Silva et al., 2019). However, the commercialization

\footnotetext{
${ }^{1}$ Submitted on: 7/18/2019. Accepted for publication on: 10/4/2019.

${ }^{2}$ Universidade Federal de Lavras, Departamento de Agricultura, Caixa Postal 3037, 37200-000 - Lavras, Minas Gerais, Brazil.

*Corresponding author $<$ douglascorrea@ymail.com $>$
} 
of this genus is still restricted due to lack of knowledge, especially regarding the agronomic management, which limits its production (Ngoroyemoto et al., 2019; Xavier et al., 2018; Xavier et al., 2019).

In this sense, aiming at encouraging the consumption and production of Amaranthus spp., knowing the quality of its seeds is crucial. Studies show that the use of seeds with high physiological potential is a factor to be considered for increasing crop yield and, therefore, seed quality control should be increasingly efficient, including tests that rapidly evaluate physiological potential and allow precise differentiation between species (Fessel et al., 2010).

As a result, some techniques have been developed, such as digital imaging as a substitute for subjective human visual evaluation (Venora et al., 2009). The use of seed and seedling images for commercial and technological purposes seeks to facilitate, speed up and automate the categorization of seed characteristics such as size, color, shape, texture, filling, seedling measurement and cultivar identification (Granitto et al., 2005). Image analysis is a fast, objective, compact and non-destructive method. Studies have been performed with X-ray equipment and GroundEye ${ }^{\circledR}$ to evaluate seed quality (Andrade et al., 2016).

Among computer systems, GroundEye ${ }^{\circledR}$ stands out for being equipment that analyzes and extracts more than 300 morphological characteristics of seeds and seedlings (Andrade et al., 2016). Another technique used is the nearinfrared spectroscopy (NIR), which determines functional groups of chemical components in seeds, according to the absorbance of the sample. This technique has been employed for identification of constituents in foods such as oil, determination of genetically modified organisms, selection and identification of genotypes, among others (Conceição et al., 2006; Silva et al., 2008; Mittelmann et al., 2006; Silverstein and Webster, 1998).

Given the lack of scientific results with Amaranthus spp. and aiming at exploring tools such as X-rays, GroundEye ${ }^{\circledR}$ and NIR, this research aimed to evaluate and distinguish the morphological, chemical and physiological characteristics of Amaranthus sp. (commercial species), A. viridis and A. hybridus.

\section{Material and Methods}

\section{Plant material}

Seeds of three Amaranthus species of the germplasm collection of unconventional vegetables of the Universidade Federal de Lavras (UFLA) were collected to develop the experiment. These species were identified by the herbarium of the Empresa de Pesquisa Agropecuária de Minas Gerais
(EPAMIG) under registration 57999, 58002 and 58003, which refers to Amaranthus sp. (commercial species), A. hybridus L. and $A$. viridis L., respectively.

The species were multiplied from October 2016 to April 2017 in the UFLA experimental area $\left(21^{\circ} 14^{\prime} \mathrm{S}\right.$ and $45^{\circ} 00^{\prime}$ $\mathrm{W}$; altitude of $919 \mathrm{~m}$ ) in a randomized block design with three replications. A physical barrier of corn was placed among the species to avoid crossbreeding since polyploidy with interspecific hybridization is common in the genus Amaranthus, masking its characteristics (Olusanya, 2017).

\section{Morphological evaluations}

After harvesting, seeds of each species were cleaned using a DeLeo ${ }^{\circledR}$ blower with air opening between 1 to $2 \mathrm{~cm}$, eliminating straw and coarse dirt from the field. Subsequently, these seeds were sieved with three meshes $(850,600$ and $425 \mu \mathrm{m})$, dividing them into three size classes. The remaining impurities were removed manually using a magnifying glass.

Then, seeds were characterized by image analysis using the GroundEye ${ }^{\circledR}$ system, NIR and radiographic analysis. For these analyses, the experiment was conducted in a completely randomized design in a $3 \times 3$ factorial scheme, in which three species and three size classes were evaluated. Three replicates were used for each treatment and each replication had 100 seeds.

Seeds were placed in the reading device tray of the GroundEye $^{\circledR}$ system v. S120 for image capture. Subsequently, the analysis setting was performed for background color calibration and the CIELab color model, with luminosity index from 0 to 100 , dimension a from -17.8 to 42.2 and dimension $b$ from -50.3 to -24.7 , was used. After background color calibration, image analysis was performed and seed biometric (area, circularity, circularity by modified circular shape factor-CSFm, shape sphericity, contour deformation, maximum diameter, minimum diameter, perimeter and thinning) and color dominance characteristics were extracted.

These seeds were fixed on transparent acetate sheets with double-sided tape and submitted to radiographic analysis. A radiation intensity of $35 \mathrm{Kv}$ and seed exposure time to X-rays of nineteen seconds were used for equipment calibration. Images were obtained by quantifying the percentage of filled seeds for each sample.

NIR evaluation was carried out with a Bruker ${ }^{\circledR}$ Tensor 27 spectrometer with the software OPUS_Spectroscopy v. 6. This analysis was conducted in eight replicates for each species, 48 scans for each replicate and resolution of $4 \mathrm{~cm}^{-1}$. The data were analyzed by partial least squares-discriminant analysis (PLS-DA) using the software PIROUETTE ${ }^{\circledR}$. 


\section{Physiological evaluations}

In order to verify the physiological quality of seeds, a germination test was performed and, at the same time, the germination speed index (GSI) of seeds was evaluated using the mixture of classes 850 and $600 \mu \mathrm{m}$ for each species, considering that the class $425 \mu \mathrm{m}$ presented empty seeds with low physical quality, according to the X-ray analysis.

The presence and absence of $0.2 \% \mathrm{KNO}_{3}$ solution to overcome dormancy was evaluated. Thus, for physiological tests, the experiment was conducted in a completely randomized design in a $3 \times 2$ factorial scheme, being evaluated species and use of $\mathrm{KNO}_{3}$, with four replications for each treatment and fifty seeds per replication.

The germination test was carried out considering the Rules for Seed Testing (Brasil, 2009), using the recommendation for the species $A$. hybridus. Seeds were placed in plastic boxes and BOD incubator. A photoperiod of eight hours of light and sixteen hours of dark, with an alternating temperature of $30-20{ }^{\circ} \mathrm{C}$, was used. Germination was performed on blotting paper by moistening it with a water volume and $0.2 \% \mathrm{KNO}_{3}$ equivalent to 2.5 times the substrate weight. The first count was performed on the fifth day and germination on the fourteenth day after test setting up. GSI of each species was obtained by Maguire (1962) equation, with daily count of normal seedlings (with the emission of the first pair of primary leaves) in the interval from the third to the fourteenth day after sowing.

Seedling, shoot and primary root length were evaluated by images captured by GroundEye ${ }^{\circledR}$ in two evaluations: first count and germination.

\section{Data analysis}

The results were analyzed with mean and standard deviation observations and the evaluations were submitted to analysis of variance and means compared by the Tukey test $(\mathrm{p}<0.05)$. Experimental precision was analyzed using the coefficient of variation (CV) and statistical analysis was performed using the software SISVAR ${ }^{\circledR}$ (Ferreira, 2011).

\section{Results and Discussion}

According to the analysis of variance for geometric characteristics evaluated by GroundEye ${ }^{\circledR}$, an interaction was observed between the studied factors (species $\times$ size classes). The slicing of species within classes showed that characteristics of the area, contour deformity, maximum diameter, minimum diameter, perimeter and thinning had the highest values for Amaranthus sp., regardless of size class (Table 1).

The seed class $425 \mu \mathrm{m}$ showed the lowest values for all geometric characteristics, except for thinning and circularity by CSFm in $A$. viridis and $A$. hybridus, possibly because this seed class has a poor formation and low germination potential. Classes 850 and $600 \mu \mathrm{m}$ did not differ from each other for circularity, circularity by CSFm and shape sphericity, while area, contour deformation, maximum diameter, minimum diameter and perimeter showed the highest values for class $850 \mu \mathrm{m}$.

The commercial species (Amaranthus sp.), regardless of seed size class, showed mean values of $0.95( \pm 0.31) \mathrm{mm}^{2}$ of area, $0.35( \pm 0.06) \mathrm{cm}$ of perimeter, $0.11( \pm 0.02) \mathrm{cm}$ of maximum diameter, $0.09( \pm 0.02) \mathrm{cm}$ of minimum diameter and $0.90( \pm 0.04)$ of circularity. On the other hand, A. viridis presented mean data of $0.71( \pm 0.19) \mathrm{mm}^{2}, 0.31( \pm 0.04) \mathrm{cm}$, $0.09( \pm 0.01) \mathrm{cm}, 0 \mathrm{~cm}, 08( \pm 0.01) \mathrm{cm}$ and $0.90( \pm 0.01) \mathrm{cm}$, while $A$. hybridus presented values of $0.69( \pm 0.17) \mathrm{mm}^{2}, 0.31$ $( \pm 0.04) \mathrm{cm}, 0.09( \pm 0.01) \mathrm{cm}, 0.07( \pm 0.01) \mathrm{cm}$ and $0.87( \pm$ $0.03) \mathrm{cm}$ for area, perimeter, maximum diameter, minimum diameter and minimum diameter, respectively.

Zapotoczny et al. (2006) observed similar results of size and shape of Amaranthus sp. seeds (variety MT-3) in the sieve class from 0.80 to $1.00 \mathrm{~mm}$ in diameter and that seeds had a mean area of $1.07 \mathrm{~mm}^{2}$, perimeter of $0.36 \mathrm{~cm}$, maximum diameter of $0.12 \mathrm{~cm}$, minimum diameter of 0.10 $\mathrm{cm}$, compaction shape factor of 1.00 and circularity of 1.00 .

The geometric characterization of Amaranthus spp. seeds can be very useful to build machines that would assist in the commercial production of these species. Studies can be carried out from these data to develop seeders, seed cleaners and small seed pelletizing.

Table 2 shows seed colors identified by GroundEye ${ }^{\circledR}$, according to sieve classes. Seeds of the species A. viridis and A. hybridus are predominantly black in the three size classes, but 83.10 and $80.50 \%$ black in the class $850 \mu \mathrm{m}$, respectively. Seeds of the commercial material (Amaranthus sp.) are predominantly yellow (57.1\%) in this class. There is also a decrease in black color in the smaller seed size class, although it is still the predominant color probably due to the seed maturity stage.

Color is an important factor in separating commercial varieties from spontaneous species. Usually, clear seeds do not have dormancy, whereas black seeds have dormancy and remain in the soil, germinating gradually. Seeds of varying color, such as black, red, gray, pink, yellow, beige and white, are found in the genus Amaranthus (Silva et al., 2018; Xavier et al., 2018). According to Vasundhara et al. (2017), color of Amaranthus spp. seeds can represent an important source of vegetable pigments that can be used as colorants.

The radiographic analysis showed an interaction between size class and species. Class $425 \mu \mathrm{m}$ showed the lowest 
Table 1. Geometric characteristics of Amaranthus spp. seeds at different sieve classes analyzed by GroundEye ${ }^{\circledR}$.

\begin{tabular}{|c|c|c|c|c|c|}
\hline Characteristic & Sieve $(\mu \mathrm{m})$ & A. viridis & A. hybridus & Amaranthus sp. & $\mathrm{CV}(\%)$ \\
\hline \multirow{3}{*}{ Area $\left(\mathrm{mm}^{2}\right)$} & 425 & $0.49 \mathrm{bC}$ & $0.51 \mathrm{bC}$ & $0.62 \mathrm{aC}$ & \multirow{3}{*}{2.69} \\
\hline & 600 & $0.76 \mathrm{bB}$ & $0.71 \mathrm{cB}$ & $0.99 \mathrm{aB}$ & \\
\hline & 850 & $0.87 \mathrm{bA}$ & $0.86 \mathrm{bA}$ & $1.25 \mathrm{aA}$ & \\
\hline \multirow{3}{*}{ Circularity } & 425 & $0.89 \mathrm{aB}$ & $0.83 \mathrm{cB}$ & $0.85 \mathrm{bB}$ & \multirow{3}{*}{0.76} \\
\hline & 600 & $0.91 \mathrm{aA}$ & $0.88 \mathrm{bA}$ & $0.92 \mathrm{aA}$ & \\
\hline & 850 & $0.91 \mathrm{bA}$ & $0.90 \mathrm{bA}$ & $0.93 \mathrm{aA}$ & \\
\hline \multirow{3}{*}{ Circularity by CSFm* } & 425 & $0.90 \mathrm{aA}$ & $0.87 \mathrm{bA}$ & $0.88 \mathrm{bB}$ & \multirow{3}{*}{0.85} \\
\hline & 600 & $0.89 \mathrm{bAB}$ & $0.88 \mathrm{bA}$ & $0.92 \mathrm{aA}$ & \\
\hline & 850 & $0.88 \mathrm{bB}$ & $0.88 \mathrm{bA}$ & $0.92 \mathrm{aA}$ & \\
\hline \multirow{3}{*}{ Shape sphericity } & 425 & $13.63 \mathrm{aB}$ & $13.84 \mathrm{aB}$ & $13.73 \mathrm{aA}$ & \multirow{3}{*}{1.41} \\
\hline & 600 & $14.27 \mathrm{aA}$ & $14.37 \mathrm{aA}$ & $13.58 \mathrm{bA}$ & \\
\hline & 850 & $14.61 \mathrm{aA}$ & $14.63 \mathrm{aA}$ & $13.62 \mathrm{bA}$ & \\
\hline \multirow{3}{*}{ Contour deformation } & 425 & $14.67 \mathrm{bC}$ & $14.88 \mathrm{abC}$ & $15.39 \mathrm{aC}$ & \multirow{3}{*}{1.48} \\
\hline & 600 & $17.51 \mathrm{bB}$ & $17.24 \mathrm{bB}$ & $19.21 \mathrm{aB}$ & \\
\hline & 850 & $18.06 \mathrm{bA}$ & $18.25 \mathrm{bA}$ & $21.31 \mathrm{aA}$ & \\
\hline \multirow{3}{*}{ Maximum diameter $(\mathrm{cm})$} & 425 & $0.08 \mathrm{cC}$ & $0.08 \mathrm{bC}$ & $0.09 \mathrm{aC}$ & \multirow{3}{*}{1.99} \\
\hline & 600 & $0.10 \mathrm{bB}$ & $0.09 \mathrm{bB}$ & $0.12 \mathrm{aB}$ & \\
\hline & 850 & $0.11 \mathrm{bA}$ & $0.11 \mathrm{bA}$ & $0.13 \mathrm{aA}$ & \\
\hline \multirow{3}{*}{ Minimum diameter $(\mathrm{cm})$} & 425 & $0.07 \mathrm{bC}$ & $0.06 \mathrm{bC}$ & $0.07 \mathrm{aC}$ & \multirow{3}{*}{1.47} \\
\hline & 600 & $0.08 \mathrm{bB}$ & $0.08 \mathrm{cB}$ & $0.10 \mathrm{aB}$ & \\
\hline & 850 & $0.09 \mathrm{bA}$ & $0.09 \mathrm{bA}$ & $0.12 \mathrm{aA}$ & \\
\hline \multirow{3}{*}{ Perimeter $(\mathrm{cm})$} & 425 & $0.26 \mathrm{bC}$ & $0.26 \mathrm{bC}$ & $0.29 \mathrm{aC}$ & \multirow{3}{*}{2.11} \\
\hline & 600 & $0.33 \mathrm{bB}$ & $0.32 \mathrm{bB}$ & $0.36 \mathrm{aB}$ & \\
\hline & 850 & $0.35 \mathrm{bA}$ & $0.35 \mathrm{bA}$ & $0.41 \mathrm{aA}$ & \\
\hline \multirow{3}{*}{ Thinning } & 425 & $0.92 \mathrm{aA}$ & $0.90 \mathrm{aA}$ & $0.91 \mathrm{aA}$ & \multirow{3}{*}{1.06} \\
\hline & 600 & $0.88 \mathrm{bB}$ & $0.87 \mathrm{bB}$ & $0.92 \mathrm{aA}$ & \\
\hline & 850 & $0.86 \mathrm{bB}$ & $0.86 \mathrm{bB}$ & $0.92 \mathrm{aA}$ & \\
\hline
\end{tabular}

Means followed by the same lowercase letter in the row and uppercase letter in the column do not differ significantly from each other by the Tukey test ( $\mathrm{p}<0.05)$. *CSFm - modified circular shape factor.

percentage of filled seeds, with $A$. hybridus presenting $27.75 \%$, followed by A. viridis and Amaranthus sp., which did not differ from each other, with a mean of $9.87 \%( \pm 2.29)$ of filled seeds. Classes 600 and $850 \mu \mathrm{m}$ did not differ among the studied species, with mean values of $97.25( \pm 2.16)$ and $99.08 \%( \pm 0.52)$ of filled seeds, respectively (Table 3$)$.

The germination test showed an interaction between the evaluated factors (use of $\mathrm{KNO}_{3} \times$ species). At the first germination count (Table 4), the commercial species (Amaranthus sp.) without the use of $\mathrm{KNO}_{3}$ presented higher percentage of normal seedlings $(58 \%)$, while using $\mathrm{KNO}_{3}$ provided the highest percentage in A. hybridus and Amaranthus sp., which did not differ from each other, with a mean value of $62.00 \%( \pm 2.12)$.

No difference was found at germination within species for the use or not of $\mathrm{KNO}_{3}$ nor between species with its use, with a mean of $82.33 \%( \pm 4.85)$ of normal seedlings. However, a difference was observed between species in the absence of $\mathrm{KNO}_{3}$, while Amaranthus sp. had the highest germination $(83.50 \%)$ and $A$. viridis presented the lowest value (65\%).

Nobre et al. (2015) evaluating four seed lots of the cultivar BRS Alegria (clear seeds) and found germination values ranging from 75 to $85 \%$. The values found in the literature are similar to those of this study.

The use of $\mathrm{KNO}_{3}$ had a positive effect on the species under study when it was evaluated in the first germination count in relation to the number of normal seedlings. Despite the positive effect of the treatment, $A$. viridis continued with the lowest percentage of normal seedlings and this species may have unknown factors that impair its vigor, as radiographic 
Table 2. Dominance of color in Amaranthus spp. seeds at different sieve classes analyzed by GroundEye ${ }^{\circledR}$.

\begin{tabular}{|c|c|c|c|c|c|c|c|}
\hline \multirow{2}{*}{ Species } & \multirow{2}{*}{ Sieve class $(\mu \mathrm{m})$} & Black & Yellow & Orange & Celestial & Dark grey & Other \\
\hline & & $(\%)$ & $(\%)$ & $(\%)$ & $(\%)$ & $(\%)$ & $(\%)$ \\
\hline \multirow{3}{*}{ A. viridis } & 425 & $65.93 \mathrm{~b}$ & - & - & $11.95 \mathrm{a}$ & $2.24 \mathrm{~b}$ & $19.87 \mathrm{a}$ \\
\hline & 600 & $83.41 \mathrm{a}$ & - & - & $8.44 \mathrm{~b}$ & $5.89 \mathrm{a}$ & $2.20 \mathrm{~b}$ \\
\hline & 850 & $83.10 \mathrm{a}$ & - & - & $8.68 \mathrm{ab}$ & $5.46 \mathrm{a}$ & $2.78 \mathrm{~b}$ \\
\hline \multicolumn{2}{|c|}{ CV (\%) } & 3.55 & - & - & - & 6.78 & 19.92 \\
\hline \multirow{3}{*}{ A. hybridus } & 425 & $67.35 \mathrm{~b}$ & - & - & $10.71 \mathrm{a}$ & $3.17 \mathrm{~b}$ & $18.75 \mathrm{a}$ \\
\hline & 600 & $79.74 \mathrm{a}$ & - & - & $9.56 \mathrm{a}$ & $5.53 \mathrm{a}$ & $5.15 \mathrm{~b}$ \\
\hline & 850 & $80.50 \mathrm{a}$ & - & - & $11.58 \mathrm{a}$ & $4.36 \mathrm{ab}$ & $3.55 \mathrm{~b}$ \\
\hline \multicolumn{2}{|c|}{ CV (\%) } & 5.48 & - & - & - & 11.79 & 24.5 \\
\hline \multirow{3}{*}{ Amaranthus sp. } & 425 & - & $28.84 \mathrm{~b}$ & $28.75 \mathrm{a}$ & $19.24 \mathrm{a}$ & $18.89 \mathrm{a}$ & $4.27 \mathrm{a}$ \\
\hline & 600 & - & $50.72 \mathrm{a}$ & $10.09 \mathrm{~b}$ & $16.70 \mathrm{~b}$ & $18.26 \mathrm{a}$ & $4.22 \mathrm{a}$ \\
\hline & 850 & - & $57.13 \mathrm{a}$ & $8.70 \mathrm{~b}$ & $14.54 \mathrm{c}$ & $15.79 \mathrm{a}$ & $3.83 \mathrm{a}$ \\
\hline \multicolumn{2}{|c|}{ CV (\%) } & - & - & 16.42 & 4.91 & 9.36 & 10.51 \\
\hline
\end{tabular}

Means followed by the same letter in the columns, within species, do not differ significantly from each other by the Tukey test $(\mathrm{p}<0.05)$.

analysis showed a high percentage of filled seeds in this species for seed sizes of 600 and $850 \mu \mathrm{m}$ (Tables 3 and 4).

However, $\mathrm{KNO}_{3}$ is important in the initial germination period of A. viridis and A. hybridus, as it increased the percentage of normal seedlings by 38.24 and $43.30 \%$, respectively. According to Ellis et al. (1983), the potential of potassium nitrate to increase the germination rate (of some species) may be related to its role as oxidant and electron acceptor. Potassium is also involved in maintaining plant cell balance, promoting respiration and carbohydrate metabolism (Aisha et al., 2007).

Several studies have been conducted with the proposal of using $\mathrm{KNO}_{3}$ to overcome seed dormancy, such as the research of Ruttanaruangboworn (2017), who evaluated its use in rice seeds and observed better results when $\mathrm{KNO}_{3}$ was at low concentrations, besides increasing germination speed and uniformity. However, the use of this substance at high concentrations may delay seed soak by phytotoxicity.

The variable GSI showed an interaction between species and the use of $\mathrm{KNO}_{3}$. The slicing showed that Amaranthus sp. presented higher GSI (8.69) without the use of this solution, with no difference between species with its use, with a mean of $7.41( \pm 1.12)$. However, no variation was observed with and without the use of $\mathrm{KNO}_{3}$, with means of $5.54( \pm 1.00)$, $7.19( \pm 0.43)$ and $8.59( \pm 0.13)$ for A. viridis, A. hybridus and Amaranthus sp., respectively (Table 5). The commercial

Table 3. Percentage of filled seeds of Amaranthus spp. according to the sieve class analyzed by X-rays.

\begin{tabular}{cccc}
\hline \multirow{2}{*}{ Species } & \multicolumn{3}{c}{ Sieve class } \\
\cline { 2 - 4 } & $425 \mu \mathrm{m}$ & $600 \mu \mathrm{m}$ & $850 \mu \mathrm{m}$ \\
\hline A. viridis & $11.50 \mathrm{bB}$ & $96.00 \mathrm{aA}$ & $99.25 \mathrm{aA}$ \\
A. hybridus & $27.75 \mathrm{bA}$ & $99.75 \mathrm{aA}$ & $98.50 \mathrm{aA}$ \\
Amaranthus sp. & $8.25 \mathrm{bB}$ & $96.00 \mathrm{aA}$ & $99.50 \mathrm{aA}$ \\
\hline CV $(\%)$ & \multicolumn{3}{c}{4.00} \\
\hline
\end{tabular}

Means followed by the same lowercase letter in the row and uppercase letter in the column do not differ significantly from each other by the Tukey test $(\mathrm{p}<0.05)$.

Table 4. Percentage of normal seedlings in the slicing of $\mathrm{KNO}_{3}$ within Amaranthus species according to first germination count (FGC) and germination (G) evaluation.

\begin{tabular}{|c|c|c|c|c|c|}
\hline \multirow{2}{*}{ Evaluation } & \multirow{2}{*}{ Use of $\mathrm{KNO}_{3}$} & \multicolumn{3}{|c|}{ Species } & \multirow{2}{*}{ CV (\%) } \\
\hline & & A. viridis & A. hybridus & Amaranthus sp. & \\
\hline \multirow{2}{*}{ FGC } & Without $\mathrm{KNO}_{3}$ & $21.00 \mathrm{cB}$ & $36.00 \mathrm{bB}$ & $58.00 \mathrm{aA}$ & \multirow{2}{*}{15.38} \\
\hline & With $\mathrm{KNO}_{3}$ & $34.00 \mathrm{bA}$ & $63.50 \mathrm{aA}$ & $60.50 \mathrm{aA}$ & \\
\hline \multirow{2}{*}{ G } & Without $\mathrm{KNO}_{3}$ & $65.00 \mathrm{bA}$ & $78.50 \mathrm{abA}$ & $83.50 \mathrm{aA}$ & \multirow{2}{*}{11.71} \\
\hline & With $\mathrm{KNO}_{3}$ & $77.00 \mathrm{aA}$ & $86.50 \mathrm{aA}$ & $83.50 \mathrm{aA}$ & \\
\hline
\end{tabular}

Means followed by the same lowercase letter in the row and uppercase letter in the column do not differ significantly from each other by the Tukey test ( $\mathrm{p}<0.05)$. 
species (Amaranthus sp.) has faster and more uniform germination, making it more competitive when established in the field compared to other species.

Seedlings were analyzed with the GroundEye ${ }^{\circledR}$ in the first germination count and germination evaluations and the shoot, primary root and total seedling length were measured, with no interaction between factors.

According to Table 6, Amaranthus sp. developed the most in this short period, with the highest significant values of the shoot, primary root and total length. It occurred because this species is already commercially cultivated in other countries, showing characteristics of growth and development of a genetically improved cultivar. A. viridis and A. hybridus presented inferior results when compared to the commercial species, but statistically equal to each other. Significantly superior results regarding the mean of the species were observed in these characteristics when $\mathrm{KNO}_{3}$ was used.

The germination test (Table 6) showed similar data to the first germination count, but with a general increase in the

Table 5. Germination speed index of Amaranthus sp. species within $\mathrm{KNO}_{3}$.

\begin{tabular}{ccc}
\hline Species & Without $\mathrm{KNO}_{3}$ & With $\mathrm{KNO}_{3}$ \\
\hline A. viridis & $4.83 \mathrm{aB}$ & $6.25 \mathrm{aA}$ \\
A. hybridus & $6.89 \mathrm{aAB}$ & $7.50 \mathrm{aA}$ \\
Amaranthus sp. & $8.69 \mathrm{aA}$ & $8.50 \mathrm{aA}$ \\
\hline $\mathrm{CV}(\%)$ & 19.25 & \\
\hline
\end{tabular}

Means followed by the same lowercase letter in the row and uppercase letter in the column do not differ significantly from each other by the Tukey test $(\mathrm{p}<0.05)$. seedling length of the species, i.e., Amaranthus sp. has the highest values, followed by $A$. viridis and $A$. hybridus. The same trend of the fifth day of evaluation was found on the fourteenth day when evaluating the influence of $\mathrm{KNO}_{3}$. Seeds soaked with solution were significantly superior to those that did not absorb $\mathrm{KNO}_{3}$, except for root size at fourteen days, not differing statistically from each other, although numerically higher with the use of this solution.

Most species of economic value of the Rules for Seed Testing (Brasil, 2009), especially large crops, do not require the use of $\mathrm{KNO}_{3}$, as they do not have dormancy. However, the application of this stimulant is often recommended for seed germination testing of forage grasses, vegetables and ornamental species, showing that the effect of $\mathrm{KNO}_{3}$ differs significantly between species.

The analysis using the NIR technique, by the visual observation of the spectra, showed that Amaranthus spp. seeds submitted to near-infrared had similar bands (Figure 1). The main objective of infrared spectroscopy is to determine functional groups of a given material. It is possible because each group absorbs, at a characteristic frequency, radiation from that region (Silverstein and Webster, 1998). This technique has made great advances in several applications, especially in the area of food science and agricultural products (Small, 2006).

From this observation, it can be inferred that the chemical composition observed among all species is similar since the spectrum shape was not discrepant between the analyzed seeds. However, this technique distinguished the three analyzed species (Table 7).

Table 6. Shoot, primary root and total length of seedlings of Amaranthus spp. evaluated at the first germination count (FGC) and germination $(\mathrm{G})$ and the influence of $\mathrm{KNO}_{3}$ use.

\begin{tabular}{|c|c|c|c|c|}
\hline Evaluation & Species & Shoot length $(\mathrm{cm})$ & Primary root length $(\mathrm{cm})$ & Total length $(\mathrm{cm})$ \\
\hline \multirow{6}{*}{ FGC } & A. viridis & $0.98 \mathrm{~b}$ & $0.98 \mathrm{~b}$ & $1.97 \mathrm{~b}$ \\
\hline & A. hybridus & $0.97 \mathrm{~b}$ & $0.92 \mathrm{~b}$ & $1.89 \mathrm{~b}$ \\
\hline & Amaranthus sp. & $1.57 \mathrm{a}$ & $1.57 \mathrm{a}$ & $3.14 \mathrm{a}$ \\
\hline & With $\mathrm{KNO}_{3}$ & $1.37 \mathrm{a}$ & $1.29 \mathrm{a}$ & $2.66 \mathrm{a}$ \\
\hline & Without $\mathrm{KNO}_{3}$ & $0.98 \mathrm{~b}$ & $1.02 \mathrm{~b}$ & $2.01 \mathrm{~b}$ \\
\hline & CV $(\%)$ & 21.97 & 16.33 & 18.49 \\
\hline \multirow{6}{*}{ G } & A. viridis & $1.58 \mathrm{ab}$ & $1.18 \mathrm{ab}$ & $2.76 \mathrm{ab}$ \\
\hline & A. hybridus & $1.39 \mathrm{~b}$ & $1.03 \mathrm{~b}$ & $2.42 \mathrm{~b}$ \\
\hline & Amaranthus sp. & $1.74 \mathrm{a}$ & $1.33 \mathrm{a}$ & $3.07 \mathrm{a}$ \\
\hline & With $\mathrm{KNO}_{3}$ & $1.73 \mathrm{a}$ & $1.20 \mathrm{a}$ & $2.93 \mathrm{a}$ \\
\hline & Without $\mathrm{KNO}_{3}$ & $1.41 \mathrm{~b}$ & $1.16 \mathrm{a}$ & $2.57 \mathrm{~b}$ \\
\hline & CV (\%) & 15.56 & 10.53 & 12.61 \\
\hline
\end{tabular}

Means followed by the same letter in the column do not differ significantly from each other by the Tukey test $(\mathrm{p}<0.05)$. 


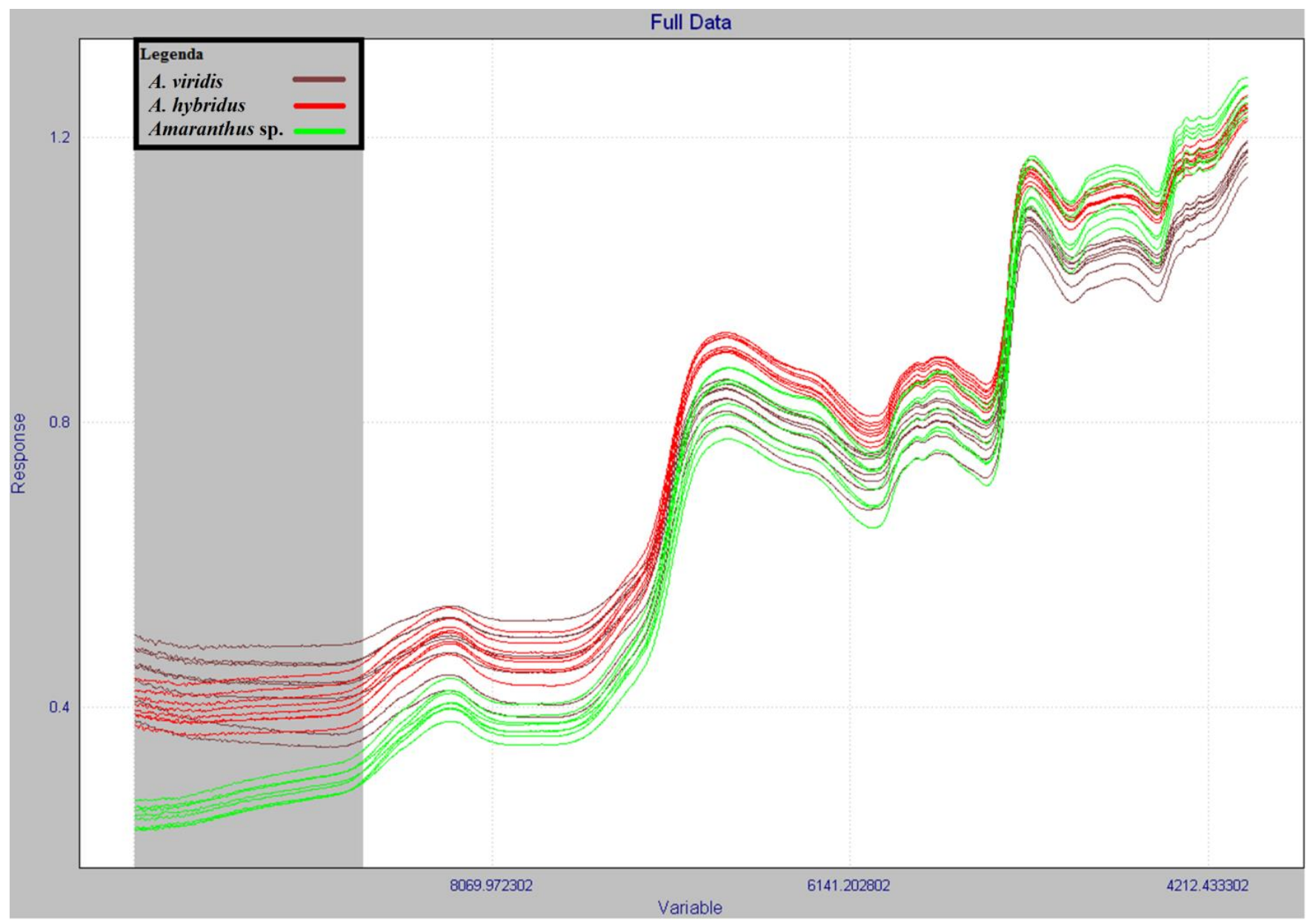

Figure 1. Spectra of Amaranthus spp. seeds subjected to near-infrared.

Table 7. Amaranthus spp. seeds classified by the near-infrared technique according to their chemical composition.

\begin{tabular}{ccccc}
\hline \multirow{2}{*}{ Species } & \multicolumn{3}{c}{ Classification } & Non-classified/Total \\
\cline { 2 - 4 } & A. viridis & A. hybridus & Amaranthus sp. & $0 / 6$ \\
A. viridis & 6 & 0 & 0 & $0 / 6$ \\
A. hybridus & 0 & 6 & 0 & $0 / 6$ \\
Amaranthus $\mathrm{sp}$. & 0 & 0 & 6 & \\
\hline
\end{tabular}

A satisfactory percentage of correct answers for calculated $r$, validated $\mathrm{r}$, calibration error and validation error was verified for the spectroscopy analysis in the model used for the differentiation of seed chemical composition. These results of calibration showed that the analysis had a satisfactory accuracy in differentiating seeds by the chemical constituents of each species. The results of model calibration and validation are shown in Table 8. Five factors (new variables constructed by statistical calculation) were used for cross-evaluation for each species.

Thus, seeds from the three species were correctly classified
Table 8. Performance parameters of the PLS-DA model (discriminant analysis) for differentiating Amaranthus spp. seeds.

\begin{tabular}{cccc}
\hline Statistics & A. viridis & A. hybridus & Amaranthus sp. \\
\hline Calculated r (\%) & 98.51 & 96.80 & 99.62 \\
Validated r (\%) & 97.12 & 92.90 & 99.11 \\
Calibration error (\%) & 9.12 & 13.30 & 4.59 \\
Validation error (\%) & 11.24 & 17.51 & 6.28 \\
\hline
\end{tabular}


in $100 \%$ of the replications (Table 8 ), with no ambiguity in their classification, i.e., the species had different chemical characteristics that segregated them. This result leads to the conclusion that although the absorption spectrum was not different for both species, different chemical components or at different amounts determined the differentiation between species by the near-infrared technique.

Therefore, there was no crossing between the three species in the field, possibly due to the corn barrier established between plots, even though polyploidy with interspecific hybridization in species of this genus is common, often masking the specific characteristics of each species (Olusanya, 2017).

The same classification pattern was observed for the validation of the model used to classify seeds according to their species (Table 9). All the species were correctly classified in $100 \%$ of the replications.

Figure 2 and Table 10 (adapted from Workman and Weyer, 2012) show the wavelengths that stand out and that were used to differentiate species from each other. For $A$. viridis (Figure $2 \mathrm{~A}$ ), the most pronounced peaks were relative to lengths of 4332,5219 and $8764 \mathrm{~cm}^{-1}$, which correspond to hydrocarbons/aliphatic compound, amide and hydrocarbon/ aromatic compounds, respectively.

For A. hybridus (Figure 2B), the main peaks are relative to lengths of 5200,6912 and $8764 \mathrm{~cm}^{-1}$, which correspond to molecular water, aromatic amine and hydrocarbon/aromatic compounds, respectively. For Amaranthus sp. (Figure 2C), the main lengths that contibuted to differentiate it from the other species were 4509,4324 and $4802 \mathrm{~cm}^{-1}$, which correspond to $\mathrm{N}-\mathrm{H}$ of urea, lipid and N-H/C-N of ovalbumin protein, respectively.

Table 9. Replications used in the validation of the model created from the studied species.

\begin{tabular}{ccccc}
\hline \multirow{2}{*}{ Species } & \multicolumn{3}{c}{ Classification } & Non-classified/Total \\
\cline { 2 - 4 } & A. viridis & A. hybridus & Amaranthus sp. & $0 / 2$ \\
A. viridis & 2 & 0 & 0 & $0 / 2$ \\
A. hybridus & 0 & 2 & 0 & $0 / 2$ \\
Amaranthus sp. & 0 & 0 & 2 & 0 \\
\hline
\end{tabular}
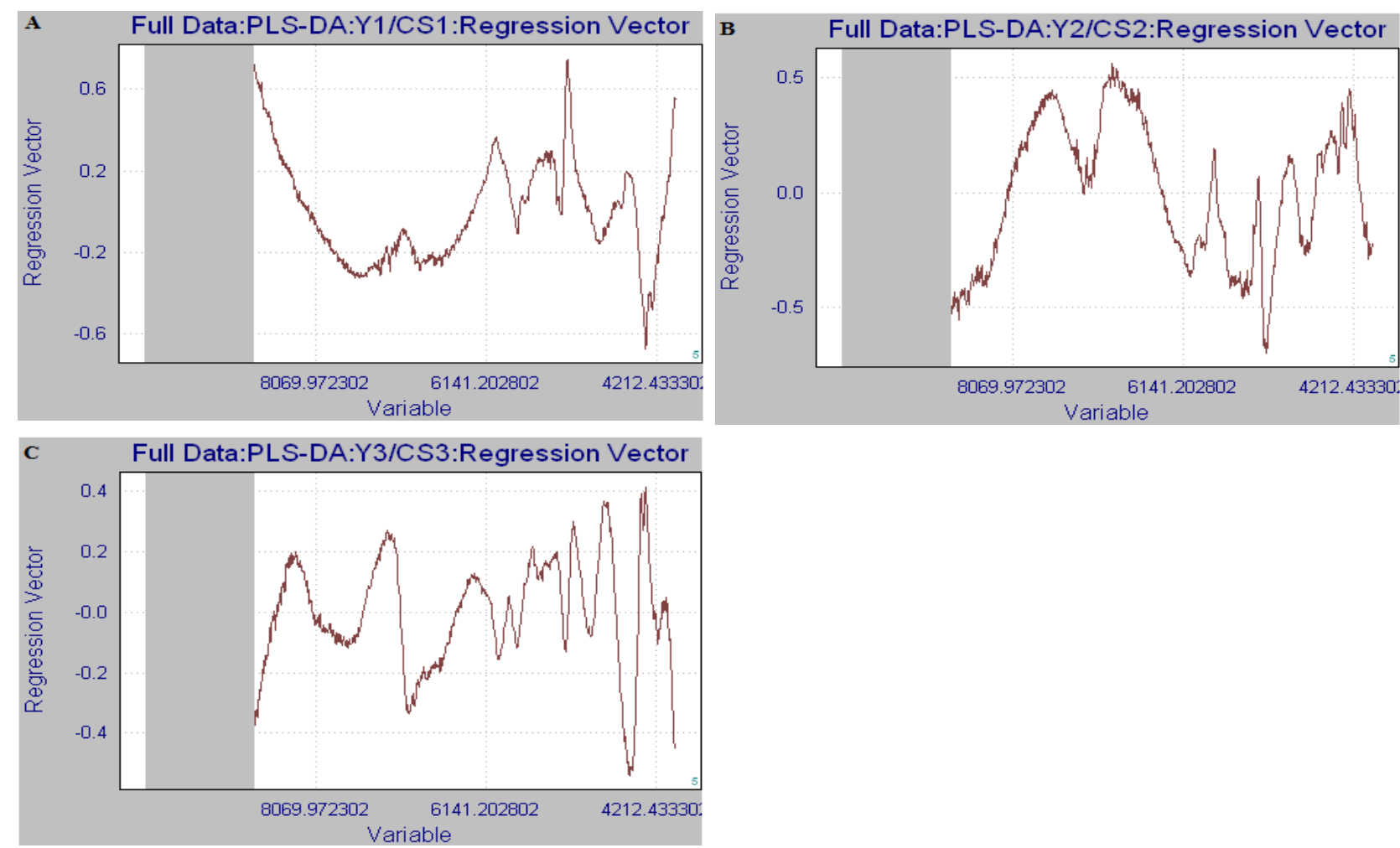

Figure 2. Wavelengths $\left(\mathrm{cm}^{-1}\right)$ for the studied species. (A) A. viridis, (B) A. hybridus and (C) Amaranthus sp. 
Table 10. Chemical functional group and type of chemical compound (Workman and Weyer, 2012) present in Amaranthus spp. seeds determined by spectral bands.

\begin{tabular}{|c|c|c|c|}
\hline Species & Spectral band $\left(\mathrm{cm}^{-1}\right)$ & Functional group & Type of compound \\
\hline \multirow{3}{*}{ A. viridis } & 4332 & $\begin{array}{l}\text { C-H Methylene C-H, associated with linear aliphatic } \\
\qquad \mathrm{R}\left(\mathrm{CH}_{2}\right)_{\mathrm{N}} \mathrm{R}\end{array}$ & Hydrocarbons, aliphatic compound \\
\hline & 5219 & $\mathrm{C}=\mathrm{O}$ Amide $(. \mathrm{C}=\mathrm{ONH})$ & Amide \\
\hline & 8764 & C-H Aromatic (ArCH) & Hydrocarbon/aromatic compounds \\
\hline \multirow{3}{*}{ A. hybridus } & 5200 & $\begin{array}{l}\text { O-H assigned to molecular water } \\
{[\mathrm{O}-\mathrm{H}(. \mathrm{O}-\mathrm{H} \& \mathrm{HOH})]}\end{array}$ & $\mathrm{O}-\mathrm{H}$ molecular water \\
\hline & 6912 & $\mathrm{~N}-\mathrm{H}$ primary aromatic amine $\left(\mathrm{o}-\mathrm{OCH}_{3}\right)$ & Aromatic amine \\
\hline & 8764 & C-H Aromatic $(\mathrm{ArCH})$ & Hydrocarbon/aromatic compounds \\
\hline \multirow{3}{*}{$\begin{array}{l}\text { Amaranthus } \\
\quad \text { sp. }\end{array}$} & 4509 & $\begin{array}{l}\mathrm{N}-\mathrm{H} \text { combination band from urea } \\
\qquad\left(\mathrm{NH}_{2}-\mathrm{C}=\mathrm{O}-\mathrm{NH}_{2}\right)\end{array}$ & U-N of urea \\
\hline & 4324 & $\mathrm{CHO}$ - Classic filter instrument & Lipid/oil \\
\hline & 4802 & $\begin{array}{l}\mathrm{O}-\mathrm{H} \text { related combination from water change in phase } \\
\text { and } \mathrm{N}-\mathrm{H} / \mathrm{C}-\mathrm{N} \text { combination band from urea }\left(\mathrm{NH}_{2}^{-}\right. \\
\left.\qquad \mathrm{C}=\mathrm{O}-\mathrm{NH}_{2}\right) \text { from ovalbumin }\end{array}$ & $\mathrm{N}-\mathrm{H} / \mathrm{C}-\mathrm{N}$ from ovalbumin protein \\
\hline
\end{tabular}

\section{Conclusions}

Seeds of Amaranthus sp. (commercial species) are light in color and larger when compared to those of $A$. viridis and A. hybridus, which are predominantly black.

The mean values of filled seeds were $97.25( \pm 2.16)$ and $99.08 \%( \pm 0.52)$ in the size class 600 and $850 \mu \mathrm{m}$, respectively, for the three studied species. The species presented germination ranging from 65 to $83.50 \%$, while GSI varied among species, with values of 5.54, 7.19 and 8.59 for A. viridis, A. hybridus and Amaranthus sp.

GroundEye $^{\circledR}$ and near-infrared spectroscopy (NIR) allowed distinguishing the three species according to their geometric characteristics, color predominance and chemical components.

\section{References}

AISHA, A.H.; RIZK, F.A.; SHAHEEN, A.M.; ABDEL-MOUTY, M.M. Onion plant growth, bulb yield and its physical and chemical properties as affected by organic and natural fertilization. Research Journal of Agriculture and Biological Sciences, v.3, n.5, p.380-388, 2007. http://www.aensiweb.net/AENSIWEB/rjabs/ rjabs/2007/380-388.pdf

AMAYA-FARFAN, J.; MARCÍLIO, R.; SPEHAR, C.R. Deveria o Brasil investir em novos grãos para a sua alimentação? A proposta do amaranto (Amaranthus sp.). Segurança Alimentar e Nutricional, v.12, n.1, p.47-56, 2005. https://doi.org/10.20396/san.v12i1.1838
ANDRADE, D.B.; OLIVEIRA, A.S.; PINTO, C.A.G.; PIRES, R.M.O.; OLIVEIRA, A.S.; SILVA, M.A.; CARVALHO, M.L.M. Detection of green seeds in soybean lots by the seed analysis system (SAS). International Journal of Current Research, v.8, n.2, p.26462, 2016. https://www.journalcra.com/sites/default/files/issuepdf/12927.pdf

BRASIL. Ministério da Agricultura, Pecuária e Abastecimento. Regras para análise de sementes. Ministério da Agricultura, Pecuária e Abastecimento. Secretaria de Defesa Agropecuária. Brasília: MAPA/ACS, 2009. 395p. http:// www.agricultura.gov.br/ arq editor/file/2946_regras analise_sementes.pdf

BRASIL. Ministério da Agricultura, Pecuária e Abastecimento: Secretaria de Desenvolvimento Agropecuário e Cooperativismo. Manual de hortaliças não convencionais. Brasília: MAPA/ACS, 2013. 99p.

CONCEIÇÃO, F.R.; MOREIRA, A.N.; BINSFELD, P.C. Detecção e quantificação de organismos geneticamente modificados em alimentos e ingredientes alimentares. Ciência Rural, v.36, n.1, p.315324, 2006. http://dx.doi.org/10.1590/S0103-84782006000100053

ELLIS, R. H.; HONG, T.D.; ROBERTS, E H. Procedures for the safe removal of dormancy from rice seed. Seed Science Technology, v.11, n.1, p.77-112, 1983.

FERREIRA, D.F. Sisvar: a computer statistical analysis system. Ciência e Agrotecnologia, v.35, n.6, p.1039-1042, 2011. http:// dx.doi.org/10.1590/S1413-70542011000600001

FESSEL, S.A.; PANOBIANCO, M.; SOUZA, C.R.; VIEIRA, R.D. Teste de condutividade elétrica em sementes de soja armazenadas sob diferentes temperaturas. Bragantia, v.69, n.1, p.207-214, 2010. http://dx.doi.org/10.1590/S0006-87052010000100026

GRANITTO, P.M.; VERDES, P.F.; CECCATO, H.A. Largescale investigation of weed seed identification by machine vision. Computers and Electronics in Agriculture, v.47, n.1, p.15-24, 2005. https://doi.org/10.1016/j.compag.2004.10.003 
KINUPP, V.F.; LORENZI, H. Plantas alimentícias não convencionais (PANC) no Brasil: guia de identificação, aspectos nutricionais e receitas ilustradas. São Paulo: Instituto Plantarum de Estudos da Flora, 2014. 768p.

MAGUIRE, J.D. Speed of germination - aid in selection and evaluation for seedling emergence and vigor. Crop Science, v.2, p.176-177, 1962. https://dl.sciencesocieties.org/publications/cs/ abstracts/2/2/CS0020020176

MITTELMANN, A.; MIRANDA-FILHO, J.B.; LIMA, G.J.M.M.; HARA-KLEIN, C.; SILVA, R.M.; TANAKA, R.T. Análise dialélica do teor de óleo em milho. Revista Brasileira de Agrociência, v.12, n.2, p.139-143, 2006. https://periodicos.ufpel.edu.br/ojs2/index.php/ CAST/article/view/4509

NOBRE, D.A.C.; SANTOS, M.G.P.; DIAS, D.C.F.S.;ALVARENGA, E.M. Qualidade fisiológica em lotes de sementes de amarantos. Cultura Agronômica, v.24, n.2, p.149-156, 2015. https://ojs.unesp. br/index.php/rculturaagronomica/article/viewFile/2289/1722

NGOROYEMOTO, N.; GUPTA, S.; KULKARNI, M.G.; FINNIE, J.F.; VAN STADEN, J. Effect of organic biostimulants on the growth and biochemical composition of Amaranthus hybridus L. South African Journal of Botany, v.124, p.87-93, 2019. https://doi. org/10.1016/j.sajb.2019.03.040

OLUSANYA, A.C. A multi-species assessment of genetic variability in Nigerian Amaranthus accessions: potential for improving intraand interspecies hybridization breeding. Archives of Agronomy and Soil Science, v.64, n.5, p.612-625, 2018. https://doi.org/10.1080/036 50340.2017.1384817

RUTTANARUANGBOWORN, A.; CHANPRASERT, W.; TOBUNLUEPOP, P.; ONWIMOL, D. Effect of seed priming with different concentrations of potassium nitrate on the pattern of seed imbibition and germination of rice (Oryza sativa L.). Journal of Integrative Agriculture, v.16, n.3, p.605-613, 2017. https://doi. org/10.1016/S2095-3119(16)61441-7

SILVA, C.F.L.; MILACH, S.C.K.; ANJOS E SILVA, S.D.; MONTERO, C.R. Near infrared reflectance spectroscopy (NIRS) to assess protein and lipid contents in Avenal sativa L. Crop Breeding and Applied Biotechnology, v.8, p.127-133, 2008. http://www.sbmp. org.br/cbab/siscbab/uploads/bd6b9df0-1532-0202.pdf

SILVA, L.F.L.; SOUZA, D.C.; RESENDE, L.V.; NASSUR, R.C.M.R.; SAMARTINI, C.Q.; GONÇALVES W.M. Nutritional evaluation of non-conventional vegetables in Brazil. Anais $d a$ Academia Brasileira de Ciências, v.90, n.2, p.1775-1787, 2018. http://dx.doi.org/10.1590/0001-3765201820170509
SILVA, L.F.L.; SOUZA, D.C.; XAVIER, J.B.; SAMARTINI, C.Q.; RESENDE, L.V. Avaliação nutricional de caruru (Amaranthus spp). Agrarian, v.12, n.45, p.411-417, 2019. https://doi.org/10.30612/ agrarian.v12i45.7770

SILVERSTEIN, R.M.; WEBSTER, F.X. Spectrometric identification of organic compounds. 6 ed. New York: Wiley, 1998.

SMALL, G.W. Chemometrics and near-infrared spectroscopy: avoiding the pitfalls. Trends in Analytical Chemistry, v.25, n.11, p.1057-1066, 2006. https://doi.org/10.1016/j.trac.2006.09.004

VASUNDHARA, M.; GUJARAN, S. R.; MARAPPA, N.; MURTHY, N.; PRIYANKA, R. Screening and identification of genotypes for natural color from Grain Amaranth (Amaranth sp.). International Journal of Agriculture, Environment and Biotechnology, v.10, n.4. p.443-447, 2017. https://doi.org/10.5958/2230-732X.2017.00055.9

VENORA, G.; GRILlO, O.; RAVALLI, C.; CREMONINI, R. Identification of Italian landraces of bean (Phaseolus vulgaris L.) using an image analysis system. Scientia Horticulturae, v.121, n.4, p.410-418, 2009. https://doi.org/10.1016/j.scienta.2009.03.014

WORKMAN, J.; WEYER, L. Practical guide and spectral atlas for interpretive near infrared spectroscopy. 2 ed. Boca Raton: CRC Press, 2012.

XAVIER, J.B.; SOUZA, D.C.; SOUZA, L.C.; GUERRA, T.S.; RESENDE, L.V.; PEREIRA, J. Nutritive potential of amaranth weed grains. African Journal of Agricultural Research, v.13, n. 22, p.1140-1147, 2018. https://doi.org/10.5897/AJAR2018.13151

XAVIER, J.B.; CASTRO, D.G.; SILVA, D.M.; ABREU, R.A.A.; SOUZA, D.C.; SILVA, M.L.S. Eficiência de absorção de nutrientes em Amaranthus spp. Magistra, v.30, p.199-210, 2019. https:// magistraonline.ufrb.edu.br/index.php/magistra/article/view/783

ZAPOTOCZNY, P.; MARKOWSKI, M.; MAJEWSKA, K.; RATAJSKI, A.; KONOPKO, H. Effect of temperature on the physical, functional and mechanical characteristics of hot-air-puffed amaranth seeds. Journal of Food Engineering, v.76, n.4, p.469-476, 2006. https://doi.org/10.1016/j.jfoodeng.2005.05.045 